\title{
Evaluation of Target Definition for Management of Myxoid Liposarcoma (MLS) with Neoadjuvant Radiation Therapy (RT)
}

\author{
Ferrat Dincoglan*, Selcuk Demiral, Omer Sager and Murat Beyzadeoglu \\ Department of Radiation Oncology, Gulhane Medical Faculty, Turkey \\ *Corresponding author: Ferrat DINCOGLAN, Department of Radiation Oncology, University of Health Sciences, Gulhane \\ Medical Faculty, Gn.Tevfik Saglam Cad. 06018, Etlik, Kecioren, Ankara / TURKEY
}

\section{ARTICLE INFO}

Received: 幽 February 01, 2021

Published: 蔧 February 10, 2021

Citation: Ferrat Dincoglan, Selcuk Demiral, Omer Sager, Murat Beyzadeoglu. Evaluation of Target Definition for Management of Myxoid Liposarcoma (MLS) with Neoadjuvant Radiation Therapy (RT). Biomed J Sci \& Tech Res 33(5)-2021. BJSTR. MS.ID.005458.

Keywords: Myxoid Liposarcoma (MLS); Neoadjuvant Radiation Therapy (RT); Magnetic Resonance Imaging (MRI)

Abbreviations: MLS: Myxoid Liposarcoma; RT: Radiation Therapy; MRI: Magnetic Resonance Imaging; CT: computed tomography; LINAC: linear accelerator; IGRT: Image Guided Radiation Therapy; ART: Adaptive Radiation Therapy; BART: Breathing Adapted Radiation Therapy; IMRT: Intensity Modulated Radiation Therapy

\begin{abstract}
Objective: Radiation therapy (RT) typically plays a major role in the management of soft tissue sarcomas. In the context of myxoid liposarcoma (MLS) management, several studies have addressed the utility of neoadjuvant RT. Longer life expectancy of patients with MLS with more efficacious treatments rendered quality of life a critical aspect of management. From this standpoint, improving the toxicity profile of radiation delivery has gained utmost priority in the millennium era. Accurate RT target definition comprises an indispensable and critical component of successful MLS management. Within this context, we assessed target definition for neoadjuvant RT of MLS in this original article.
\end{abstract}

Materials and Methods: A comparative evaluation was performed regarding target definition with multimodality imaging by incorporation of magnetic resonance imaging (MRI) or by computed tomography (CT)-simulation images only for patients receiving neoadjuvant RT for MLS.

Results: Priorities in RT planning included encompassing of target volumes adequately with optimal sparing of critical structures. Determination of ground truth target volume was performed by the board-certified radiation oncologists after meticulous assessment, collaboration, colleague peer review, and ultimate consensus. Target definition by CT-only imaging and by CT-MR fusion based imaging was assessed with comparative analysis. Ground truth target volume was found to be identical with target volume determination by CT-MR fusion based imaging as the primary endpoint result of the study.

Conclusion: Multimodality imaging should be considered for target definition of MLS for neoadjuvant radiotherapeutic management. Clearly, further studies are warranted to address this issue.

\section{Introduction}

Liposarcomas constitute a considerable proportion of soft tissue sarcomas [1]. Among the various subtypes of liposarcoma, myxoid liposarcoma (MLS) represents a distinct pathological entity which is characterized by tumor cells within a myxoid stroma with rich, branching thin-walled vasculature, and focal lipomatous differentiation [2-4]. This distinctive subtype of liposarcomas may have a hypercellular round cell component, and a propensity for metastasis to fat bearing areas including the bone marrow, mediastinum, and retroperitoneum may be observed [2-4]. Patients suffering from liposarcomas may present with various symptoms depending on disease location and association with critical neurovascular structures. Surgery, chemotherapy, and radiation therapy (RT) are among the therapeutic options. RT typically plays a major role in the management of soft tissue sarcomas [5]. In the context of MLS management, several studies have addressed the utility of neoadjuvant RT $[4,6,7]$. Longer life expectancy of patients with MLS with more efficacious treatments rendered quality of life a critical aspect of management. From this standpoint, improving the toxicity profile of radiation delivery has gained utmost priority in the millennium era. Accurate RT target definition comprises an indispensable and critical component of successful MLS management. Within this context, we assessed target definition for neoadjuvant RT of MLS in this original article. 


\section{Materials and Methods}

A comparative evaluation was performed regarding target definition with multimodality imaging by incorporation of magnetic resonance imaging (MRI) or by computed tomography (CT)-simulation images only for patients receiving neoadjuvant RT for MLS. Ground truth target volume which served as the reference for actual treatment and comparison purposes was meticulously outlined by board certified radiation oncologists after comprehensive assessment, colleague peer review, collaboration, and ultimate consensus. Thorough patient evaluation was performed considering the lesion size, localization, symptomatology, patient preferences, and projected outcomes of management. CT-simulator (GE Lightspeed RT, GE Healthcare, Chalfont St. Giles, UK) was used in RT simulation. Planning CT images were acquired and sent to the contouring workstation (SimMD, GE, UK) via the network for delineation of treatment volumes and critical structures. Either CTsimulation images only or fused CT and MR images were utilized for target volume definition for neoadjuvant RT. Target determination with CT only and with incorporation of CT-MR fusion was evaluated with comparative analysis. Treatment was delivered by use of Synergy (Elekta, UK) linear accelerator (LINAC) with the capability of Image Guided Radiation Therapy (IGRT).

\section{Results}

Treatment planning procedure for neoadjuvantradiotherapeutic management of MLS patients was accomplished by the available RT planning systems at our tertiary referral institution. Priorities in RT planning included encompassing of target volumes adequately with optimal sparing of critical structures. Determination of ground truth target volume was performed by the board certified radiation oncologists after meticulous assessment, collaboration, colleague peer review, and ultimate consensus. Synergy (Elekta, UK) LINAC was used for RT administration. Target definition by CT-only imaging and by CT-MR fusion based imaging was assessed with comparative analysis. Ground truth target volume was found to be identical with target volume determination by CT-MR fusion based imaging as the primary endpoint result of the study.

\section{Discussion}

Soft tissue sarcomas may be observed at several locations throughout the human body. MLS is a distinct subtype of soft tissue sarcoma with specific features. RT has been utilized for management of MLS with encouraging treatment outcomes [4-7]. Nevertheless, there is room for further progress in management to achieve improved therapeutic ratio. RT planning for MLS is typically based on CT-simulation. CT is a viable imaging modality for initial assessment of disease extent and may provide valuable information for staging. Mineralization and osseous changes along with presence or absence of distant metastases may also be assessed by use of CT. However, initial evaluation of extremity and other superficial soft tissue sarcomas may be superiorly performed by use of MRI. Incorporation of MRI in target definition for neoadjuvant RT of MLS may offer several advantages including improved soft tissue contrast and capability of multiplanar assessment. Artificial intelligence-based applications have facilitated several steps of the RT workflow with excellent image registration, reconstruction, segmentation, and automated planning tools.

Within this context, it has now been easier to exploit the advantages of multimodality imaging in radiotherapeutic management of MLS. Indeed, many studies have investigated incorporation of multimodality imaging in target definition for RT [8-27]. Recently, substantial advances have taken place in the discipline of radiation oncology with introduction of adaptive irradiation strategies and modernized treatment delivery techniques and equipment with incorporation of Adaptive Radiation Therapy (ART), Breathing Adapted Radiation Therapy (BART), Intensity Modulated Radiation Therapy (IMRT), Image Guided Radiation Therapy (IGRT), automatic segmentation methods, molecular imaging techniques, and stereotactic irradiation approaches [28-63]. With respect to MLS management, studies have addressed the utility of neoadjuvant RT [4-7]. Quality of life a has been a more important endpoint of contemporary management approaches with longer life expectancy of patients by effective therapies. Within this context, improving the toxicity profile of radiation delivery has gained increasing priority in the era of artificial intelligence and state of the art treatment strategies. In conclusion, multimodality imaging should be considered for target definition of MLS for neoadjuvant radiotherapeutic management. Clearly, further studies are warranted to address this issue. There are no conflicts of interest and no acknowledgements.

\section{References}

1. Nassif NA, Tseng W, Borges C, Chen P, Eisenberg B, et al. (2016) Recent advances in the management of liposarcoma. F1000Res 5: 2907.

2. Dürr HR, Rauh J, Baur Melnyk A, Knösel T, Lindner L, et al. (2018) Myxoid liposarcoma: local relapse and metastatic pattern in 43 patients. BMC Cancer 18(1): 304.

3. Chowdhry V, Goldberg S, DeLaney TF, Cote GM, Chebib I, et al. (2018) Myxoid Liposarcoma: Treatment Outcomes from Chemotherapy and Radiation Therapy. Sarcoma 2018: 8029157.

4. Engström K, Bergh P, Cederlund CG, Hultborn R, Willen H, et al. (2007) Irradiation of myxoid/round cell liposarcoma induces volume reduction and lipoma-like morphology. Acta Oncol 46(6): 838-845.

5. Wortman JR, Tirumani SH, Jagannathan JP, Rosenthal MH, Shinagare AB, et al. (2016) Radiation Therapy for Soft-Tissue Sarcomas: A Primer for Radiologists. Radiographics 36(2): 554-572.

6. Koseła Paterczyk H, Spałek M, Borkowska A, Teterycz P, Wągrodzki M, et al. (2020) Hypofractionated Radiotherapy in Locally Advanced Myxoid Liposarcomas of Extremities or Trunk Wall: Results of a Single-Arm Prospective Clinical Trial. J Clin Med 9(8): 2471.

7. Koseła-Paterczyk H, Szumera Ciećkiewicz A, Szacht M, Haas R, Morysiński T, et al. (2016) Efficacy of neoadjuvant hypofractionated radiotherapy in patients with locally advanced myxoid liposarcoma. Eur J Surg Oncol 42(6): 891-898. 
8. Sager O, Dincoglan F, Demiral S, Beyzadeoglu M (2020) Assessment of Target Volume Definition for Irradiation of Hemangiopericytomas: An Original Article. Canc Therapy \& Oncol Int J 17(2).

9. Demiral S, Beyzadeoglu M, Dincoglan F, Sager O (2020) Evaluation of Radiosurgery Target Volume Definition for Tectal Gliomas with Incorporation of Magnetic Resonance Imaging (MRI): An Original Article. Biomedical Journal of Scientific \& Technical Research (BJSTR) 27: 20543-20547.

10. Sager O, Dincoglan F, Demiral S, Beyzadeoglu M (2020) Evaluation of Treatment Volume Determination for Irradiation of chordoma: An Original Article. International Journal of Research Studies in Medical and Health Sciences 5 (10): 3-8.

11. Dincoglan F, Beyzadeoglu M, Demiral S, Sager 0 (2020) Assessment of Treatment Volume Definition for Irradiation of Spinal Ependymomas: An Original Article. ARC Journal of Cancer Science 6: 1-6.

12. Dincoglan F, Demiral S, Sager O, Beyzadeoglu M (2020) Utility of Multimodality Imaging Based Target Volume Definition for Radiosurgery of Trigeminal Neuralgia: An Original Article. Biomed J Sci \& Tech Res 26: 19728-19732.

13. Sager O, Dincoglan F, Demiral S, Beyzadeoglu M (2020) Evaluation of Target Volume Determination for Irradiation of Pilocytic Astrocytomas: An Original Article. ARC Journal of Cancer Science 6: 1-5.

14. Sager O, Demiral S, Dincoglan F, Beyzadeoglu M (2020) Target Volume Definition for Stereotactic Radiosurgery (SRS) Of Cerebral Cavernous Malformations (CCMs). Canc Therapy \& Oncol Int J 15: 555917.

15. Beyzadeoglu M, Dincoglan F, Sager O, Demiral S (2020) Determination of Radiosurgery Treatment Volume for Intracranial Germ Cell Tumors (GCTS). Asian Journal of Pharmacy, Nursing and Medical Sciences 8(3): 18-23.

16. Demiral S, Beyzadeoglu M, Dincoglan F, Sager O (2020) Assessment of Target Volume Definition for Radiosurgery of Atypical Meningiomas with Multimodality Imaging. Journal of Hematology and Oncology Research 3: 14-21.

17. Sager O, Dincoglan F, Demiral S, Beyzadeoglu M (2020) Radiosurgery Treatment Volume Determination for Brain Lymphomas with and without Incorporation of Multimodality Imaging. Journal of Medical Pharmaceutical and Allied Sciences 9: 2398-2404.

18. Beyzadeoglu M, Dincoglan F, Demiral S, Sager O (2020) Target Volume Determination for Precise Radiation Therapy (RT) of Central Neurocytoma: An Original Article. International Journal of Research Studies in Medical and Health Sciences 5: 29-34.

19. Dincoglan F, Sager O, Demiral S, Beyzadeoglu M (2019) Incorporation of Multimodality Imaging in Radiosurgery Planning for Craniopharyngiomas: An Original Article. SAJ Cancer Sci 6: 103.

20. Sager O, Dincoglan F, Demiral S, Gamsiz H, Uysal B, et al. (2019) Evaluation of the Impact of Magnetic Resonance Imaging (MRI) on Gross Tumor Volume (GTV) Definition for Radiation Treatment Planning (RTP) of Inoperable High-Grade Gliomas (HGGs). Concepts in Magnetic Resonance Part A 2019: 4282754.

21. Demiral S, Sager O, Dincoglan F, Beyzadeoglu M (2019) Assessment of Computed Tomography (CT) And Magnetic Resonance Imaging (MRI) Based Radiosurgery Treatment Planning for Pituitary Adenomas. Canc Therapy \& Oncol Int J 13(2): 555857.

22. Demiral S, Sager O, Dincoglan F, Beyzadeoglu M (2019) Assessment of target definition based on Multimodality imaging for radiosurgical Management of glomus jugulare tumors (GJTs). Canc Therapy \& Oncol Int J 15(2): 555909.

23. Sager O, Dincoglan F, Demiral S, Gamsiz H, Uysal B, et al. (2019) Utility of Magnetic Resonance Imaging (Imaging) in Target Volume Definition for Radiosurgery of Acoustic Neuromas. Int J Cancer Clin Res 6: 119.

24. Sager O, Dincoglan F, Demiral S, Beyzadeoglu M (2019) Evaluation of Radiosurgery Target Volume Determination for Meningiomas Based on
Computed Tomography (CT) And Magnetic Resonance Imaging (MRI). Cancer Sci Res Open Access 5: 1-4.

25. Dincoglan F, Sager O, Demiral S, Beyzadeoglu M (2019) Multimodality Imaging for Radiosurgical Management of Arteriovenous Malformations. Asian Journal of Pharmacy, Nursing and Medical Sciences 7(1): 7-12.

26. Beyzadeoglu M, Sager O, Dincoglan F, Demiral S (2019) Evaluation of Target Definition for Stereotactic Reirradiation of Recurrent Glioblastoma. Arch Can Res 7: 3.

27. Demiral S, Sager O, Dincoglan F, Uysal B, Gamsiz H, et al. (2018) Evaluation of Target Volume Determination for Single Session Stereotactic Radiosurgery (SRS) of Brain Metastases. Canc Therapy \& Oncol Int J 12(5): 555848.

28. Sager O, Dincoglan F, Demiral S, Uysal B, Gamsiz H, et al. (2020) Adaptive radiation therapy of breast cancer by repeated imaging during irradiation. World J Radiol 12(5): 68-75.

29. Sager O, Dincoglan F, Demiral S, Uysal B, Gamsiz H, et al. (2019) Breathing adapted radiation therapy for leukemia relapse in the breast: A case report. World J Clin Oncol 10(11): 369-374.

30. Sager O, Dincoglan F, Demiral S, Uysal B, Gamsiz H, et al. (2019) Utility of Molecular Imaging with 2-Deoxy-2-[Fluorine-18] Fluoro-DGlucose Positron Emission Tomography (18F-FDG PET) for Small Cell Lung Cancer (SCLC): A Radiation Oncology Perspective. Curr Radiopharm 12(1): 4-10.

31. Sager O, Dincoglan F, Uysal B, Demiral S, Gamsiz H, et al. (2018) Evaluation of adaptive radiotherapy (ART) by use of replanning the tumor bed boost with repeated computed tomography (CT) simulation after whole breast irradiation (WBI) for breast cancer patients having clinically evident seroma. Jpn J Radiol 36(6): 401-406.

32. Sager O, Dincoglan F, Uysal B, Demiral S, Gamsiz H, et al. (2017) Splenic Irradiation: A Concise Review of the Literature. J App Hem Bl Tran 1: 101.

33. Sager O, Beyzadeoglu M, Dincoglan F, Demiral S, Uysal B, et al. (2015) Adaptive splenic radiotherapy for symptomatic splenomegaly management in myeloproliferative disorders. Tumori 101(1): 84-90.

34. Ozsavaş EE, Telatar Z, Dirican B, Sager O, Beyzadeoğlu M, et al. (2014) Automatic segmentation of anatomical structures from CT scans of thorax for RTP. Comput Math Methods Med 2014: 472890.

35. Dincoglan F, Beyzadeoglu M, Sager O, Oysul K, Kahya YE, et al. (2013) Dosimetric evaluation of critical organs at risk in mastectomized leftsided breast cancer radiotherapy using breath-hold technique. Tumori 99(1): 76-82

36. Sager O, Beyzadeoglu M, Dincoglan F, Oysul K, Kahya YE, et al. (2012) Evaluation of active breathing control-moderate deep inspiration breath-hold in definitive non-small cell lung cancer radiotherapy. Neoplasma 59(3): 333-340.

37. Sağer Ö, Dinçoğlan F, Gamsiz H, Demiral S, Uysal B, et al. (2012) Evaluation of the impact of integrated [18f]-fluoro-2-deoxy-D-glucose positron emission tomography/computed tomography imaging on staging and radiotherapy treatment volume definition of nonsmall cell lung cancer. Gulhane Med J 54(3): 220-227.

38. Sager O, Beyzadeoglu M, Dincoglan F, Oysul K, Kahya YE, et al. (2012) The Role of Active Breathing Control-Moderate Deep Inspiration BreathHold (ABC-mDIBH) Usage in non-Mastectomized Left-sided Breast Cancer Radiotherapy: A Dosimetric Evaluation. UHOD - Uluslararasi Hematoloji-Onkoloji Dergisi 22(3): 147-155.

39. Sager O, Beyzadeoglu M, Dincoglan F, Demiral S, Gamsiz H, et al. (2020) Multimodality management of cavernous sinus meningiomas with less extensive surgery followed by subsequent irradiation: Implications for an improved toxicity profile. J Surg Surgical Res 6: 056-061.

40. Dincoglan F, Beyzadeoglu M, Sager O, Demiral S, Uysal B, et al. (2020) A Concise Review of Irradiation for Temporal Bone Chemodectomas (TBC). Arch Otolaryngol Rhinol 6: 016-020. 
41. Beyzadeoglu M, Sager O, Dincoglan F, Demiral S, Uysal B, et al. (2020) Single Fraction Stereotactic Radiosurgery (SRS) versus Fractionated Stereotactic Radiotherapy (FSRT) for Vestibular Schwannoma (VS). Surg Surgical Res 6: 062-066.

42. Dincoglan F, Sager O, Demiral S, Gamsiz H, Uysal B, et al. (2019) Fractionated stereotactic radiosurgery for locally recurrent brain metastases after failed stereotactic radiosurgery. Indian J Cancer 56(2): 151-156.

43. Dincoglan F, Sager O, Uysal B, Demiral S, Gamsiz H, et al. (2019) Evaluation of hypofractionated stereotactic radiotherapy (HFSRT) to the resection cavity after surgical resection of brain metastases: A single center experience. Indian J Cancer 56(3): 202-206.

44. Demiral S, Dincoglan F, Sager O, Uysal B, Gamsiz H, et al. (2018) Contemporary Management of Meningiomas with Radiosurgery. Int J Radiol Imaging Technol 80: 187-190.

45. Dincoglan F, Sager O, Demiral S, Uysal B, Gamsiz H, et al. (2017) Radiosurgery for recurrent glioblastoma: A review article. Neurol Disord Therap 1: 1-5.

46. Demiral S, Dincoglan F, Sager O, Gamsiz H, Uysal B, et al. (2016) Hypofractionated stereotactic radiotherapy (HFSRT) for who grade anterior clinoid meningiomas (ACM). Jpn J Radiol 34(11): 730-737.

47. Gamsiz H, Beyzadeoglu M, Sager O, Demiral S, Dincoglan F, et al. (2015) Evaluation of stereotactic body radiation therapy in the management of adrenal metastases from non-small cell lung cancer. Tumori 101(1): 98103.

48. Dincoglan F, Beyzadeoglu M, Sager O, Demiral S, Gamsiz H, et al. (2015) Management of patients with recurrent glioblastoma using hypofractionated stereotactic radiotherapy. Tumori 101(2): 179-184.

49. Sager O, Dincoglan F, Beyzadeoglu M (2015) Stereotactic radiosurgery of glomus jugulare tumors: Current concepts, recent advances and future perspectives. CNS Oncol 4(2): 105-114.

50. Gamsiz H, Beyzadeoglu M, Sager O, Dincoglan F, Demiral S, et al. (2014) Management of pulmonary oligometastases by stereotactic body radiotherapy. Tumori 100(2): 179-183.

51. Demiral S, Beyzadeoglu M, Sager O, Dincoglan F, Gamsiz H, et al (2014) Evaluation of Linear Accelerator (Linac)-Based Stereotactic Radiosurgery (Srs) for the Treatment of Craniopharyngiomas. UHODUluslararasi Hematoloji Onkoloji Dergisi 24(2): 123-129.

52. Demiral S, Beyzadeoglu M, Sager O, Dincoglan F, Gamsiz H, et al. (2014) Evaluation of linear accelerator (linac)-based stereotactic radiosurgery (srs) for the treatment of craniopharyngiomas. UHOD - Uluslararasi Hematoloji-Onkoloji Dergisi 24(2): 123-129.

ISSN: 2574-1241

DOI: 10.26717/BJSTR.2021.33.005458

Ferrat Dincoglan. Biomed J Sci \& Tech Res

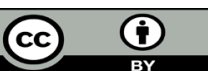

This work is licensed under Creative Commons Attribution 4.0 License

Submission Link: https://biomedres.us/submit-manuscript.php
53. Dincoglan F, Sager O, Gamsiz H, Uysal B, Demiral S, et al. (2014) Management of patients with $\geq 4$ brain metastases using stereotactic radiosurgery boost after whole brain irradiation. Tumori 100(2): 302306.

54. Sager O, Beyzadeoglu M, Dincoglan F, Uysal B, Gamsiz H, et al. (2014) Evaluation of linear accelerator (LINAC)-based stereotactic radiosurgery (SRS) for cerebral cavernous malformations: A 15-year single-center experience. Ann Saudi Med 34(1): 54-58.

55. Sager 0, Beyzadeoglu M, Dincoglan F, Gamsiz H, Demiral S, et al. (2014) Evaluation of linear accelerator-based stereotactic radiosurgery in the management of glomus jugulare tumors. Tumori 100(2): 184-188.

56. Sager O, Beyzadeoglu M, Dincoglan F, Demiral S, Uysal B, et al. (2013) Management of vestibular schwannomas with linear accelerator-based stereotactic radiosurgery: a single center experience. Tumori 99(5): 617-622.

57. Demiral S, Beyzadeoglu M, Uysal B, Oysul K, Kahya YE, et al. (2013) Evaluation of stereotactic body radiotherapy (SBRT) boost in the management of endometrial cancer. Neoplasma 60(3): 322-327.

58. Dincoglan F, Beyzadeoglu M, Sager O, Uysal B, Demiral S, et al. (2013) Evaluation of linear accelerator-based stereotactic radiosurgery in the management of meningiomas: A single center experience. J BUON 18(3): 717-722.

59. Dincoglan F, Sager O, Gamsiz H, Uysal B, Demiral S, et al. (2012) Stereotactic radiosurgery for intracranial tumors: A single center experience. Gulhane Med J 54(3): 190-198.

60. Dincoglan F, Beyzadeoglu M, Sager 0, Oysul K, Sirin S, et al. (2012) Image-guided positioning in intracranial non-invasive stereotactic radiosurgery for the treatment of brain metastasis. Tumori 98(5): 630635.

61. Sirin S, Oysul K, Surenkok S, Sager O, Dincoglan F, et al. (2011) Linear accelerator-based stereotactic radiosurgery in recurrent glioblastoma: A single center experience. Vojnosanit Pregl 68(11): 961-966.

62. Sager O, Dincoglan F, Demiral S, Uysal B, Gamsiz H, et al. (2021) Omission of Radiation Therapy (RT) for Metaplastic Breast Cancer (MBC): A Review Article. International Journal of Research Studies in Medical and Health Sciences 6: 10-15.

63. Demiral S, Sager O, Dincoglan F, Uysal B, Gamsiz H, et al. (2021) Evaluation of breathing-adapted radiation therapy for right-sided early stage breast cancer patients. Indian J Cancer 2021.

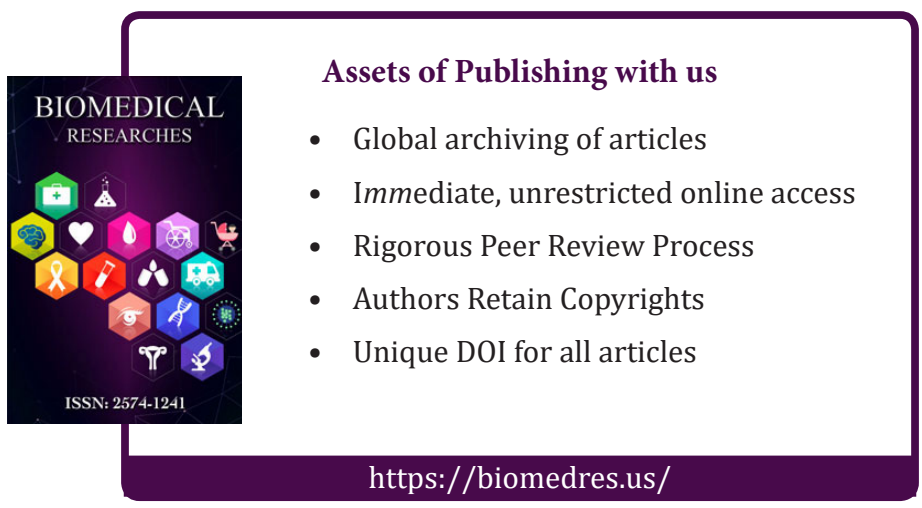

Copyright@ Ferrat Dincoglan | Biomed J Sci \& Tech Res | BJSTR. MS.ID.005458. 